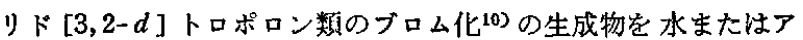
ルカリで処理して $N$-アセチルートリブロムコルヒノールや 7-1 ソプロピルー6ーキノリノール誘導体へ転位する。

$3,5,7$-トリブロムトロポロンと亜䂜酸ナトリウムの反応によっ てブロムがニトロ基で交換された 3,7-ジブロム-5-ニトロトロポ ロンの他に0-位のブロムがニトロ基で交換され, さらに転位脱炭 酸を起した 2,4-ジブロム-6-ニトロフェノールが得られたことは 興味あることである。なおこの反応機構については検討中である。

\section{3 実験}

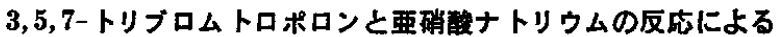
2,4-ジブロム-6-ニトロフェノール(III) の生成

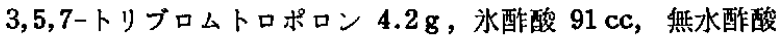
10) K. Yamane, Bull. Chem. Soc. Japan 34, 42 (1961).
ナトリウム $1.1 \mathrm{~g}$ の溶液を泠却およびかきまぜながらこの溶液中 に亜硝酸ナトリウム $0.91 \mathrm{~g}$ を少しずつ加える。さらに4 時間か きまぜたのち，析出した赤色結晶(3,7-ジブロム-5-ニトロトロポ ロンのナトリウム擦）(主生成物）を別し，そのロ液から酢酸を 減圧で留去し, 少量の水を加え不溶物をロ別しアルコールから 1 回再結晶後, 減圧で昇華し黄色昇華物をアルコールから再結晶精 製すると, 黄色柱状結晶, $\mathrm{mp} 116^{\circ} \sim 117^{\circ} \mathrm{C}, 0.23 \mathrm{~g}$ (収量 6.6 \%)を得る。これは 2,4-ジブロム-6-ニトロフェノールの純品と 混融して融点降下を示さず, 紫外, 赤外吸収スペクトルもこれと 一致する。

分析值 C $24.35 \%, \mathrm{H} 1.30 \%, \mathrm{~N} 4.51 \%$ $\mathrm{C}_{6} \mathrm{H}_{3} \mathrm{O}_{3} \mathrm{NBr}_{2}$ としての

計算值 C $24.27 \%$, H $1.02 \%, \mathrm{~N} 4.72 \%$ 終りに本実験に協力された板野宏略氏に感謝申上げる。

\title{
「ピリダジンチオール誘導体の合成」の訂正
}

(昭和 38 年 9 月 14 日受理)

熊 谷 万平・板 東 理 文†

著者の 1 人熊谷以はさに数種の3-クロルピりダジン誘導体か らチオ㽷素との反応により相当するチオール誘導体を合成し，そ のなかで 3-アミノ-6-クロルピリダシン（Ia）にチオ尿素を作用 させ,イソチウロニウム塩を経て相当するチオール誘導体(Ia) を 得たと報告したが，ての後これが誤りであることがわかった。6

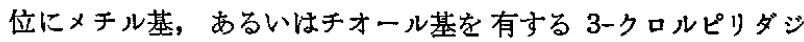
ンの場合にはチオ尿素との反応によって容易にチオール誘導体が 得られるのに反し，6位にアミノ基が存在するとチオ尿素と反忘 しないのはアミノ基の強い共鳴効果によって 3 位の塩素原子の反 応性がいちじるしく弱められる結果と考えられる。堀江ら1は 3アミノー6-クロルピリダジン(1a) を水硫化ナトリウムとオートク レーブ中 $120^{\circ} \sim 140^{\circ} \mathrm{C}, 5 \sim 8$ 時問加熱してはじめてチオール誘 導体を得ている。そこで著者らはアミノ基にアシル基あるいはス ルホニル基を導入してアミノ基による共吼効果を減少させてチオ 尿素との反応を試みたところ容易にチオール誘導体が得られるこ とを見いだした。すなわちアセチル体(Ib)，ベンゾイル体(Ic) およびスルホニル体 (Id)をエタノール中チオ尿素と加熱すると おそらくまずイソチウロニウム塩を生じるものと思われるがこの ものは単離できず，直接チオール化合物 $(\mathrm{I} \mathrm{b} \sim \mathrm{d})$ が得られた。な お 3-アセトアミノー6ークロルピリダジンオールからアルカリ加 水分解により 3-アミノー6-ピりダジンチオール(耳a)茂得られた。<smiles>Nc1ccc(Cl)cc1</smiles>

Ia: $\mathrm{R}=\mathrm{H}$

Ib: $\mathrm{R}=\mathrm{COCH}_{3}$

Ic: $\mathrm{R}=\mathrm{COC}_{6} \mathrm{H}_{5}$

Id: $\mathrm{R}=\mathrm{SO}_{2} \mathrm{C}_{6} \mathrm{H}_{4} \mathrm{CH}_{3}(\mathrm{P})$

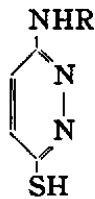

la: $\mathrm{R}=\mathrm{H}$

Ib: $\mathrm{R}=\mathrm{COCH}_{3}$

Ic: $\mathrm{R}=\mathrm{COC}_{6} \mathrm{H}_{3}$

Id: $\mathrm{R}=\mathrm{SO}_{2} \mathrm{C}_{6} \mathrm{H}_{4} \mathrm{CH}_{3}(\mathrm{P})$

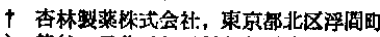

1) 能谷, 日化 81, $1604(1960)$.

2) T. Horie, K. Kinjo, T. Ueda, Chem. pharm. Bull. 10, 580(1962).

\section{1 実 験 の 部}

1.1 3-アセトアミノ-6-クロルピリダジン

3-アミノ-6-クロルピリダジン $1.3 \mathrm{~g}$ に無水酢酸 $5 \mathrm{~g}$, 氷酢酸 $5 \mathrm{cc}$ を加えて 2 時間加熱還流する。冷後沈殿を口集し水でよく 洗い，さらに少量のメタノールで洗い粗製の 3-アセトアミノ-6クロルピリダジン $1.3 \mathrm{~g}(76 \%)$ を得た。氷酢酸で再結晶すると $\mathrm{mp} 250^{\circ} \mathrm{C}$ (分解)の無色針状結晶となる。

分析值 $\mathrm{N} 24.78 \%$

$\mathrm{C}_{6} \mathrm{H}_{6} \mathrm{ON}_{3} \mathrm{Cl}_{3}$ としての計算值 $\mathrm{N} 24.48 \%$

1.2 3-アセトアミノー6-ピリダジンチオール

3-アセトアミノ-6-クロルピリダジン $1.8 \mathrm{~g}$, チオ㲾素 $0.76 \mathrm{~g}$ を加え土夕ノール $20 \mathrm{ml}$ と水浴上 4 時間加熱還流する。冷後沈 殿を口集しメタノールで洗い粗製の 3-アセトアミノー6-ピリダシ

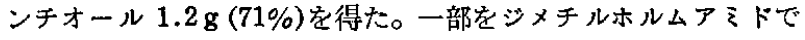
再結晶すると $\mathrm{mp} 300^{\circ} \mathrm{C}$ 以上, 黄色細針状結晶となる。

分析值 C $43.15 \%, \mathrm{H} 4.14 \%, \mathrm{~N} 24.86 \%$

$\mathrm{C}_{6} \mathrm{H}_{7} \mathrm{ON}_{3} \mathrm{~S}$ として

計算值 C $42.61 \%, \mathrm{H} 4.16 \%, \mathrm{~N} 24.83 \%$

1.3 3-アミノ-6-ピリタジンチオール

3-アセトアミノー6ーピリダジンチオール $1.7 \mathrm{~g}$ を水酸化ナトリ ウム $1.3 \mathrm{~g}$ を含む $10 \%$ 水溶液に加えて水浴上 1 時間加熱する。 冷後希酢酸を加え生じる沈殿を口過し，水一メタノールで洗う。 これを $20 \%$ 塭酸に溶汃し活性炭を加え口過し, 口液を炭酸ナト リウムの飽和溶液で中和すると粗製の黄色の結晶性粉末を得た。 これを希酢酸で再結晶する。 $\mathrm{mp} 285^{\circ} \mathrm{C}$ (分解), 黄色リン片状 結晶。イオウの試験陽性。

分析值 C $37.84 \%, \mathrm{H} 4.21 \%, \mathrm{~N} 33.06 \%$

計算值 C $37.80 \%, \mathrm{H} 3.97 \%, \mathrm{~N} 33.35 \%$

1.4 3-(p-トルエンスルホンアミド)-6-クロルピリダジン 
塩化 $p$-トルエンスルホニル $2.1 \mathrm{~g}$ 壱乾燥ピリダジン $2.0 \mathrm{ml}$ 加え，これに 3-アミノ-6-クロルピリダジン $1.3 \mathrm{~g}$ を加えよくふ りまぜ室温で 24 時間放置したのち, 水酸化ナトりウム $0.5 \mathrm{~g}$ を 含む水中に注入し希酢酸を大量に加えるとしばらくして沈殿が析 出してくる。約 30 分間放置したのち, 沈殿を口集し水でよく洗 うと粗製の 3-(p-トルエンスルホンアミド)-6-クロルピりダジン $1.9 \mathrm{~g}(67 \%)$ を得た。これを $70 \%$ ×タノールで再結晶すると, $\mathrm{mp} 154^{\circ} \mathrm{C}$, 無色針状結晶となる。

分析值 $\mathrm{N} 14.97 \%$

$\mathrm{C}_{11} \mathrm{H}_{10} \mathrm{O}_{2} \mathrm{~N}_{3} \mathrm{SCl}$ としての計算值 $\mathrm{N} 14.85 \%$

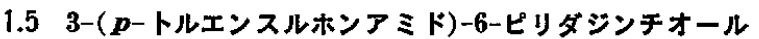
3-( チオ尿素 $0.38 \mathrm{~g}$ Kエタノール $20 \mathrm{ml}$ を加え水浴上 4 時間加熱逧 流し, エタノールを留去後 $2 \mathrm{~N}$ 水酸化ナトリウムの水溶液に溶か し, 活性炭を加えて口過し，口液を希䣷酸で酸性にすると沈殿を 生じる。これを口集しよく水で洗うと粗製の 3-(p-トルエンスル ホンアミド)-6-ピリダジンチオール $0.8 \mathrm{~g}(86 \%)$ を得た。氷酢酸 で再結晶する。 $\mathrm{mp} 209^{\circ} \mathrm{C}$, 黄色結晶性粉末。塩素の試験陰性。

行析值 $\mathrm{N} 15.03 \%$

$\mathrm{C}_{11} \mathrm{H}_{11} \mathrm{O}_{2} \mathrm{~S}_{2} \mathrm{~N}_{3}$ としての計算值 $\mathrm{N} 14.94 \%$

\subsection{3-ベンゾイルアミノ-6-クロルピリダジン}

3-ア々ノ-6-クロルピリダジン $1.3 \mathrm{~g}$ を乾燥ピリダジン約 10 $\mathrm{m} l$ 加元，氷冷しながら徐々に塩化ベンゾイル $1.4 \mathrm{~g}$ を滴下する。 約 2 時間水冷放置し, $50^{\circ} \mathrm{C}$ で 1 時間加温し, 冷後 $50 \mathrm{ml}$ の水劣 加え析出する 3-ベンゾイルアミノ-6-クロルピリダジンをロ集, 水洗する。収量 $1.6 \mathrm{~g}(72 \%)$ 。70\% メタノールあるいは希酢酸 で再結晶し $\mathrm{mp} 196^{\circ} \mathrm{C}$, 無色針状結晶を得た。

分析值 $\mathrm{N} 17.72 \%$

$\mathrm{C}_{11} \mathrm{H}_{8} \mathrm{ON}_{3} \mathrm{Cl}$ としての計算值 $\mathrm{N} 18.00 \%$

\subsection{3-ベンゾイルアミノー6-ピリダジンチオール}

3-ベンゾイルアミノー6-クロルピリダジン $1.2 \mathrm{~g}$ ，チオ尿素 0.4 $\mathrm{g}$ をエタール $20 \mathrm{~m} l$ 中で 4 時間加熱還流し, 冷後口過, 口液 のエタノールを留去し，残留物を永水酸化ナトリウム水溶液に 溶かし活性炭を加え口過, 口液を肴酶酸で酸性にすると 3-ベン ゾイルアミノー6ーピリダジンチオールが析出する。収量 $0.9 \mathrm{~g}$ $(77.5 \%) 。 50 \%$ メタノールで再結晶すると $\mathrm{mp} 225^{\circ} \mathrm{C}$ の黄色針 状結晶となる。塭素の反応陰性。

$\mathrm{C}_{11} \mathrm{H}_{9} \mathrm{ON}_{3} \mathrm{~S}$ としての

分析值 C $57.43 \%, \mathrm{H} 4.35 \%, \mathrm{~N} 17.94 \%$

計算值 C $57.14 \%$, H $3.92 \% ， \mathrm{~N} 18.18 \%$

正 誤 表

後藤, 吐山, 日化 84, 104 (1963) 左段, 上加ら6 行目

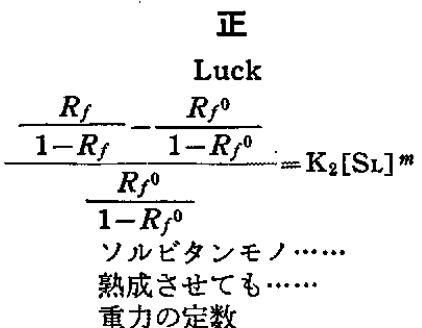

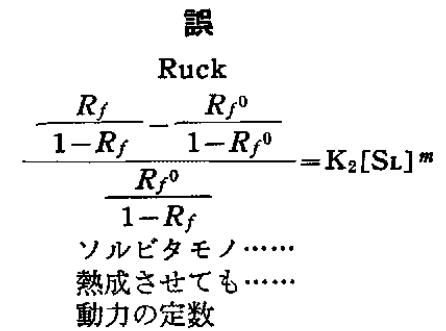

$\Delta^{r} \mathrm{Li}=m_{n}\left(\frac{r_{n}}{1+r_{n}}-\frac{r_{0}}{1+r_{0}}\right)$ $W_{z}^{\prime} 34.14$

$W_{\bar{z}}=1 / 2$
$\left(W_{z}^{\prime}+W_{z}\right)$ 25.97

$3 \mathrm{mg} / 100 \mathrm{ml}$

小松, 春藤, 日化 84, 585 (1963) 右段, 下から11行目 岡, 加藤, 佐々木, 日化 84, 589 (1963) 表 2, 半減期攔 2 行目

$\begin{array}{ll}" \text { " } & 7 \text { 行目 } \\ " 1 & 12 \text { 行目 } \\ " 1 & 22 \text { 行目 } \\ \text { " } & 25 \text { 行目 } \\ & 26 \text { 行目 }\end{array}$

$50 \mathrm{~min}$

$10.5 \mathrm{~min}$

$18.7 \mathrm{~min}$

$18.7 \mathrm{~min}$

$9.73 \mathrm{~min}$

三井, 飯島，増子，日化 84，836（1963）左段, 構造式

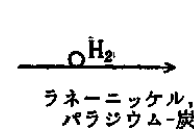<smiles>CCC(C)c1ccccc1</smiles>

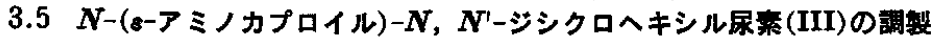

3.6 ヒアミノカプロン酸(II)と DCC との反応

昭和 38 年 12 月 5 日 时刷 発行兼洞集人 印刷人 田刷所
昭和 38 年 12 月 10 日発行 東京都千代田区(神田局区内) 神田駿河台 1 丁目 5 番㘩 東 京都 北 区 上 中 里 町 1 の 35 東 京都北区上中里町 1 の 35
〔定価 280 円（送料30円）〕

岩城広吉
倉沢直男 株式会社双交社

発 行 所 東京都干代田区(神田局区内)神田酸河台 1 丁目 5 番地

社団 日 本 化 学 会 振替眝金口座東京 6058 番 (C) 1963 The Chemical Society of Japan 